\title{
FRACTAL VARIATIONS OF RESEARCH AND TEACHING IN TOP RANKING UNIVERSITIES IN ASIA AND THE WORLD
}

\author{
Helen B. Boholano \\ Michelle Mae J. Olvido \\ Marili B. Cardillo
}

Cebu Normal University, Philippines

\begin{abstract}
This paper shows the variations of teaching and research in the performance of the top ranking universities in Asia and the World. The researchers found out that research involves knowledge production and teaching involves knowledge transmission, and that these are discrete activities in the university. Fractal features and analysis were used in this study in additional texture parameters. Observations are seen that in Higher Education Institutions (HEIs), a great emphasis is placed upon the conduct of research and thus other areas, including Teaching, may be given a lesser priority. Results revealed that research is highly correlated with teaching. Most of the faculty members focus more on research as one of the criteria in the top ranking universities.
\end{abstract}

\subsection{Introduction}

Teaching performance and production of research in higher education institution is one of its top priorities. Several international debates about the relationship between research and teaching emerged because of it's of several research findings that are inconsistent. Program evaluations may use different criteria, indicators and parameters depending on the purposes of evaluation (Boholano, Cardillo \& Olvido, 2013). In the Philippines, the Commission on Higher Education (CHED) and Professional Regulation Commission (PRC) are the monitoring and evaluating higher education agencies and list their ranking per licensure examination results. This has produced much debate about its accuracy and usefulness. The expanding diversity in rating methodologies and accompanying criticisms of each indicate the lack of consensus in the field.

According to Senaratne and Amaratunga (n.d.), University research and teaching has been viewed by academics in different ways (Robertson \& 
Bond, 2001). Healey (2000) and Brew (2003) state that the way that academics interpret the terms research, scholarship and teaching can influence on the R\&T relationship.

There are some studies that opine that the claimed synergy between research and teaching difficult to support in the institutional levels. In his monumental longitudinal study of higher education in the United States, Astin (1994) as cited in Prince, Felder \& Brent (2007) found a significant negative correlation between a university's research orientation and a number of educational outcomes. This study concluded that "attending a college whose faculty is heavily research-oriented increases student dissatisfaction and impacts negatively on most measures of cognitive and affective development and attending a college that is strongly oriented toward student development shows the opposite pattern of effects."

This article describes and analyzes the relationship of teaching and research as one of the criteria in ranking higher education institutions. As cited by Senaratne and Amaratunga (_n.d.) in Lindsay et al (2002), academics believe that research and teaching is one of 'symbiosis'; 'mutuality'; and, 'synergy', especially when lecturer's research activity increased in quantity and quality. The findings of this paper reveal that the relationship between teaching and research in the top universities in Asia and the World differ when subjected to Fractal Analysis.

\subsection{Short Literature Review}

The condition of the academic profession today is examined with a focus on the teaching and research functions in the academy. Thus, for most faculty positions in academia, teaching is a significant requirement of the job. Much of the international debate about the relationship between research and teaching is characterized by its differences. Individuals vary widely in their views about the nature of the linkage. As cited by Healy 2005,"some believe university research often detracts from the quality of teaching" (Pocklington and Tupper 2002) while others argue that "courses taught by those at the cutting edge of research will necessarily be of higher quality than those taught by those merely using the research results of others - whatever the apparent quality of their style of delivery” (Lee 2004: 9).

However Hattie and Marsh (1996) found no significant relationship between research productivity and teaching effectiveness; on the other hand, "there is clear evidence from a range of studies in different types of institutions of students valuing learning in a research-based environment" (Jenkins 2004: 29). In general, student ratings tend to be statistically reliable, valid, and relatively free from bias and need for control. Nevertheless, they are only one source of data about teaching and must be used with multiple sources of data to make judgments about all the components of teaching. 
One scenario that can be considered is looking into the context of comparing Ontario universities to American universities as done by Anderssen (2012). He reports that the teaching load among faculty in California is 46-per-cent higher - and students are more likely to be taught by full-time faculty. This resulted to the state's expenditure of 21-per-cent less on faculty time for research - with that time concentrated among faculty at the research intensive institutions - yet has still managed to produce 25 Nobel prizes since 1995, as well two public universities in the top 15 of the prestigious Time Higher Education World University Rankings, released this month. Canadian universities, on the other hand, fell in the rankings - with none placing in the top 20 - a result that led to several of the country's university presidents calling for a more focused approach to research.

In constructing links between research and teaching the discipline is an important mediator (Healey and Jenkins, 2003). This is because the conduct of research and the teaching approaches tend to differ between disciplines. This often leads disciplines to act as distinct 'academic tribes' (Becher and Trowler 2001) or 'communities of practice' (Wenger 1998). at the level of broad disciplinary groups, there are differences apparent in the way in which research and teaching tends to be conducted. These, in turn, influence the opportunities available for staff and students to link research and teaching (LTSN 2004).

Given the importance of disciplines in the self-identity of academics and the learning styles of students, it might be expected that the nature of the research-teaching links varies between disciplines.

Teaching, as well as research, is also becoming more heterogeneous. Different approaches to teaching are reflected in different ways of linking with research. Teacher-focused approaches emphasized transmission of research knowledge to a student audience, whereas student-focused approaches emphasized students constructing their own knowledge through active participation in class.

Prince, Felder and Brent (2007) sees that "first-class teaching and first-class research are each effectively full-time jobs, so that time spent on one activity is generally time taken away from the other". This could lead to asking whether the knowledge generation function of universities get in the way of instruction. As presented by Anderssen (2012), "can institutions with a deeply ingrained "publish-or-perish" culture give teaching its due, or is it time, as some observers have suggested, to create new institutions that make teaching undergraduates their focus?” The present scenario in education arena stressed more on research rather that teaching. 


\subsection{Methodology}

The attribute variation in a fractal object can be described through fractal dimension, which is a measure of the roughness, or fragmentation, of the object. More jagged-looking objects have larger fractal dimensions (Boholano, Cardillo \& Olvido, 2013). It is said that the higher the fractal dimension is, the more squiggly the object that is inside the square.

In this study, the researchers utilized data from the 2013 Times Higher Education Quality Survey (THEQS) in terms of research and teaching in both Asia and the World.

\subsection{Results and Discussion}

\begin{tabular}{|c|c|c|}
\hline & Asia & World \\
\hline Research (x) & 1.16 & 0.696 \\
\hline Teaching (y) & 1.07 & 0.273 \\
\hline Research, Teaching & 1.34 & 1.78 \\
\hline Fractal Correlation & 0.532 & 1.01 \\
\hline
\end{tabular}

Looking at the table above, we see that in Asia, the variation in Research scores is only partially correlated to Teaching. This means that the top-ranking universities in Asia see teaching and research in different levels but there is insufficient proof to conclude that this is because of the two factors in consideration. This is supported by the findings of Boholano, Cardillo \& Olvido (2013) that Asian universities that got into the top 100 ranking are consistent in being scored in great variation in terms of Teaching and Research.

On the other hand, the data on the table above portrays a different scenario in the World Rankings. There is a significant correlation between the ruggedness of Research scores to the ruggedness of Teaching scores. This highlights the finding of Boholano, Cardillo \& Olvido (2013) that highperforming schools in the World level puts varied levels of importance to Teaching and yet is more consistent in the premium they put on Research. Furthermore, this paper supports the idea that the variety in the importance they place upon Teaching is caused by the significance they put upon Research.

Observations are seen that in Higher Education Institutions (HEIs), a great emphasis is placed upon the conduct of research and thus other areas, including Teaching, may be given a lesser priority. This idea is supported by the findings in this paper where there is indeed a correlation between the ruggedness of both data sets. This may mean that because resources of the HEIs are largely apportioned to Research, lesser resources are given to Teaching. This evidence adds to the conversation wherein performance of universities should be largely evaluated upon their Research outputs even if 
this means Teaching, which is a function of any educational institution is not given equal importance.

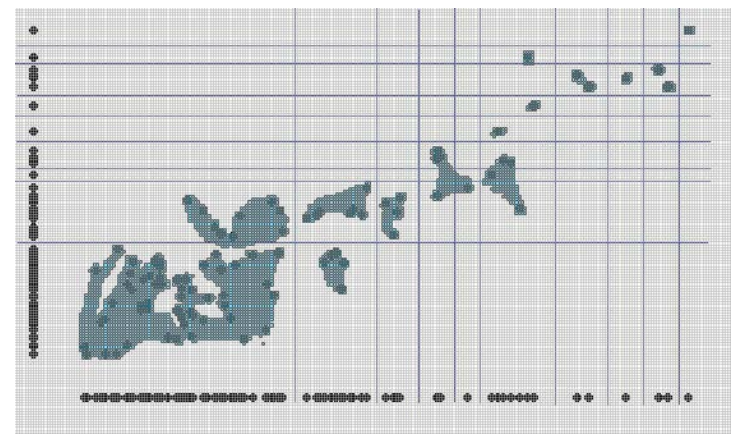

Figure 1. Fractogram of Top Performing Universities in Asia in terms of Research and Teaching

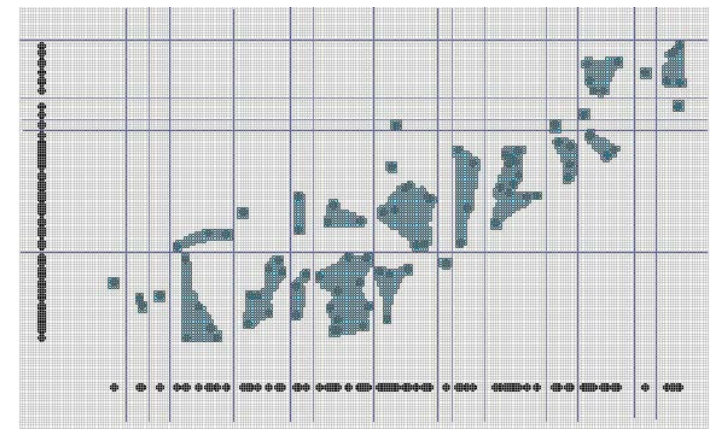

Figure 2. Fractogram of Top Performing Universities in the World in terms of T \& R

\subsection{Conclusion}

There is a high positive relationship between performance in teaching and research in the top ranking universities in the World. On the hand, a small positive relationship between performance in teaching and research in the top ranking universities in Asia.

\section{References:}

Astin, A.W., What Matters in College? Four Critical Years Revisited, San Francisco, CA: Jossey-Bass Inc., 1994.

Allison, G. T., \& Zelikow, P. D. (1999). Essence of decision: Explaining the Cuban missile crisis ( $2^{\text {nd }}$ ed.). New York: Longman.

Barnett, R (ed) (2005) Reshaping the University: New Relationships between Research, Scholarship and Teaching. McGraw Hill / Open University Press, pp.67-78

Senaratne, S. and Amaratunga, D. (n.d.). Principles Research into Teaching in Higher Education: A Knowledge Transfer Perspective. Retrieved from: http://usir.salford.ac.uk/9910/1/188_Senaratna_S_and_Amaratunga_PRINCI PLES_OF_INTEGRATING_RESEARCH_INTO_TEACHING_IN_HIGHE R_EDUCATION.pdf

The Ministry of Education. (2004, February 10). 2003-2007 Jiaoyu zhengxing xingdong jihua [The rejuvenation action plan for education 20032007]. Retrieved Feb. 12, 2013, from the China's Central People's Government Web Site: http://www.gov.cn/zwgk/2005-08/12/content_ 21704.htm 